\title{
MEMÓRIA E IDENTIDADE NEGRA NA OBRA DE GILBERTO GIL ${ }^{i}$
}

MEMORIA NEGRA E IDENTIDAD EN LA OBRA DE GILBERTO GIL

BLACK MEMORY AND IDENTITY IN THE WORK OF GILBERTO GIL

DOI: $10.22481 /$ rbba.v10i01.8799

Samuel Sousa Silva Universidade Estadual do Sudoeste da Bahia, Bahia, Brasil. ID Lattes: http://lattes.cnpq.br/1814031785967471

ORCID: https://orcid.org/0000-0001-79242-966 Endereço eletrônico: samuelsousa.adv.prof@gmail.com

\section{RESUMO}

O presente artigo tem como propósito demonstrar de que maneira as questões da memória e da identidade negra são abordadas nas canções do compositor e cantor brasileiro Gilberto Gil. Ao longo da sua carreira artística ele tem composto e interpretado muitas canções populares que se engajam nas lutas pelas memórias da negritude brasileira. Parte da sua obra nesta temática denuncia o preconceito racial e suas mazelas. Outra parte celebra a cultura da população afrodescendente, com suas estéticas e formas de resistência. Buscou-se neste texto relacionar as questões da negritude abordadas pelo compositor com discursões acerca das políticas de memórias do Estado nacional.

Palavras-chave: Gilberto Gil; Identidade Negra; Memória. 


\title{
RESUMEN
}

El propósito de este artículo es demostrar cómo se abordan los temas de la memoria y la identidad negra en las canciones del compositor y cantante brasileño Gilberto Gil. A lo largo de su carrera artística ha compuesto e interpretado numerosas canciones populares que se ocupan de las luchas por la memoria de la negritud brasileña. Una parte de su obra sobre este tema denuncia los prejuicios raciales y sus males. Otra parte celebra la cultura de la población afrodescendiente, con su estética y formas de resistencia. Este texto pretende relacionar las cuestiones de negritud abordadas por el compositor con los debates sobre las políticas de memoria del Estado nacional.

Palabras Clave: Gilberto Gil; Identidad Negra; Memoria.

\begin{abstract}
The purpose of this article is to demonstrate how the questions of Memory and black identity are addressed in the songs of the Brazilian composer, Gilberto Gil. Throughout his artistic career he has composed and performed many popular songs that engage in struggles for memories of Brazilian blackness. Part of his work on this theme denounces racial prejudice and its ailments. Another part celebrates Afro-descendant culture, its aesthetics and forms of resistance.
\end{abstract}

Keywords: Gilberto Gil; Black Identity; Memory.

\section{INTRODUÇÃO}

No final dos anos 1960, a condição de arte engajada foi se tornando uma das características da música popular produzida no Brasil. Aquele foi o momento em que a MPB (Música Popular Brasileira), tomaria contornos definitivos como a música nacional popular do país (NAPOLITANO \& VILLAÇA, 2016) e muitos cantores(as) e compositores(as) inauguraram novos olhares para a sociedade brasileira, de conteúdo fortemente caracterizados pela crítica social e política. (NERCOLINI, 2016; NAPOLITANO, 2007).

No rol dos músicos que contribuíram para essa nova agenda está Gilberto Gil (1942) Negro, de origem da classe média do interior da Bahia, esse artista, ao longo do tempo, se firmou como um dos mais profícuos compositores nacionais, tendo uma vasta obra, com 
diversos temas, dentre os quais as vivências, os problemas e os dilemas da população preta e mestiça do país. A intenção deste artigo é demonstrar de que maneira as questões da memória e da identidade negra são abordadas nas canções que o cantor e compositor Gilberto Gil popularizou, por meio de vários discos que ele gravou entre os anos de 1966 e 2000. - sendo que a maior parte destas canções são de sua autoria (LOPES, 2011; VELLOSO,2002; GIL \& ZAPPA, 2013).

\section{Tropicália, uma tradição inventada?}

O presente texto defende que o tema da negritude na obra de Gilberto Gil é uma herança do movimento cultural do qual ele é um dos fundadores: a Tropicália. Por sua vez, a Tropicália é um tipo de manifestação da memória coletiva. Por isso, faz-se necessária uma prévia explicação deste conceito e, em seguida, sobre o que foi aquele movimento cultural e qual a sua pertinência.

Memória coletiva é um conceito desenvolvido por Maurice Halbwachs (1990) e quer dizer que os indivíduos adquirem lembranças através de experiências que foram vivenciadas coletivamente. A expressão surgiu a partir dos estudos daquele autor os quais inauguraram o campo da Memória como uma ciência autônoma entre as Ciências Sociais e Humanas. Para Halbwachs (1990), a família e as primeiras comunidades afetivas dos indivíduos se constituem também nos primeiros locus onde eles ancoram as suas lembranças, portanto são os primeiros quadros sociais de memória.

A Tropicália (ou o Tropicalismo) foi um movimento cultural e artístico surgido no fim da década de 1960 que se caracterizou como um tipo de vanguarda. O seu propósito era de produzir uma estética atualizada para a cultura nacional, levando em consideração as manifestações culturais internas anteriores e contemporâneas, os principais acontecimentos do mundo na época como os movimentos de juventude - o movimento hippye, a contracultura, a Revolução Sexual, etc. - a luta contra o imperialismo, as lutas pelos Direitos Civis nos EUA, a Pop Art, dentre outros (NAPOLITANO \& VILLAÇA, 2016; NERCOLINI, 2016; VELOSO, 1997). Oficialmente, a Tropicália nasceu em 1968 com as gravações dos discos: Caetano Veloso (de Caetano Veloso), Gilberto Gil (de Gilberto Gil) e Grande Liquidação (de Tom Zé).

No âmbito da política nacional, a Tropicália, se reivindicava como uma forma de luta contra a Ditadura Militar, ora instalada no país (1964-1985) e, até certa medida, como uma forma de protesto contra as injustiças sociais do Brasil. Do ponto de vista musical, o 
tropicalismo se considerava como herdeiro da "linha evolutiva" que a bossa nova ousara alcançar (VELOSO, 1997). Tratou-se de incorporar linhas melódicas comuns da música norteamericana, sobretudo do rock in roll. (NAPOLITANO \& VILLAÇA, 2016; NERCOLINI, 2016).

O movimento, contudo, também tinha uma intenção mais audaciosa: pretendia ser uma atualização da cultura nacional, incorporando em seu acervo novas abordagens. NERCOLINI, 2016). Portanto, se reivindicava como evolução de uma tradição histórica que herdara o samba, a música caipira, a bossa nova e outros gêneros surgidos no Brasil. Em outras palavras, e isto importa muito dizer, a Tropicália tinha a intenção de ser parte da memória nacional. Decorre disso o fato de que as suas bases teóricas tinham algumas convergências notáveis com vários campos do pensamento, dentre os quais as ideias de Gilberto Freyre - cuja interpretação (e projeto) de Brasil era de que a mestiçagem é uma forma de fortalecimento da democracia - e a ideia de antropofagia difundida pelo Movimento Modernista de 1920, que defendia a inclusão de culturas estrangeiras no Brasil, desde que elas se dialogassem e se misturassem à cultura nacional (NAPOLITANO \& VILLAÇA, 2016).

A própria canção Domingo no Parque (RENNÓ, 2000), cuja primeira apresentação em 1967 pode ser considerada uma prévia do movimento (PEREIRA, 2015), se configura em um dos seus principais arquétipos. Lançada por Gilberto Gil, acompanhado da banda Mutantes no III Festival de Música Popular Brasileira, da TV Record, essa música obteve o segundo lugar na classificação final (GIL \& ZAPPA, 2013) e, mesmo antes de ser gravada em disco, já trazia os principais projetos do movimento diria mais tarde o próprio Caetano Veloso (1997), e a necessidade de voz às identidades do Brasil silenciadas ao longo da História. Preliminarmente, é preciso que fique claro que neste texto Identidade é uma expressão que advém do termo idem, que quer dizer a "relação de um sujeito com o outro" (PRADINI, 2015), e é o conjunto de memórias e subjetividades compartilhadas entre indivíduos de um lugar, dentre os quais os seus bens simbólicos e suas culturas. Sendo assim, é possível que uma pessoa tenha mais de uma identidade ao mesmo tempo, tendo em vista que ela se constitui como sujeito através marcos sociais (como: a classe social, a etnia, a religião, a nação, etc.).

Na canção, a questão da identidade negra é observável à primeira vista, pois a sua narrativa gira em torno de personagens pertencentes aos extratos sociais baixos. (CARVALHO, 2016; PEREIRA, 2015). É possível que sejam, inclusive, afrodescendentes, uma vez que os 
locais onde se desenrolam os fatos narrados são áreas de subúrbio da cidade de Salvador, cuja população é predominantemente negra, sobretudo entre os trabalhadores (CARVALHO, 2016).

Essa abordagem da identidade negra na canção nacional popular é também a marca de uma nova tradição, que a Tropicália desejava inaugurar. (GIL \& ZAPPA, 2013, VELOSO, 1997) e isso remete a outra percepção: que o movimento pode ser considerado como um tipo de fenômeno que Eric Hobsbawm e Terence Ranger (2014) classificaram como formas de tradições inventadas. O que isso quer dizer? A tese desses autores é que os Estados nacionais, ao se constituírem como tal, necessitam de uma ideologia galgada na legitimação de um passado memorável. Assim, muitas tradições que parecem ou são consideradas antigas, na verdade, são recentes - e muitas vezes totalmente inventadas. Exemplos não faltam: os desfiles e símbolos e patronos escolhidos em certas datas comemorativas (MEDEIROS 2015); os eventos culturais que caracterizam a nação, etc. (VIANNA, 1997), podem ser considerados tradições inventadas. Elas já existiam antes da memória nacional reclamar como parte de si, mas eram elementos localizados ou com importância menor para os sujeitos da nação. São então, em algum momento, ressignificadas como algo inolvidável e ao mesmo tempo vivo, pelo Estado nacional, através dos seus meios de memória - como nas escolas, nos livros didáticos, nos programas midiáticos e datas comemorativas.

Nesse sentido, há uma convergência entre o pensamento de Hobsbawm e Ranger, com o de Halbwachs (1990) e seus predecessores (NAMER, 1990, MENESES, 1992, POLLAK 1989), uma vez que para o campo da Memória a função da História tem sido de ser Históriamemória, ou seja, ter um papel conservador, cujas atribuições é celebrar e dar legitimidade à memória oficial da nação (NORA, 1993). A memória nacional, assim como a História, é uma das formas de legitimar um passado em comum da coletividade. Porém, se trata de um passado não autêntico, posto que ela selecione quais os fatos que devem ser lembrados ou esquecidos pela nação, tendo sempre em vista a estabilidade do domínio ideológico da classe dominante (MENESES, 1992; SILVA, 2002). É por esse motivo que o Estado nacional cria, ou deixa atuarem através de outras instituições, as políticas de silenciamento de memórias (quando ainda há possibilidade de se recuperar a memória perdida) e até mesmo o apagamento de memórias (quando já não há possibilidade de recuperação) (NORA, 1993).

Enfatizando, o Estado nacional é a forma mais elaborada de um grupo (NAMER, 1990) numa visão do campo da Memória. Mas numa perspectiva marxista o Estado é também o “comitê organizador da burguesia." É por meio dele que essa classe opera os seus mecanismos 
de dominação, de imposição da sua ideologia, cuja intenção é mascarar a luta de classe existente no âmago da sociedade capitalista, criando ilusões falsas da realidade, com intenção de convencer, de algum modo, que a exploração do proletariado seja algo natural e inevitável e até justo.

Com essa finalidade, a classe dominante busca impor à sociedade, os discursos que lhes sejam benéficos, que lhes exaltem como modelos de vida a serem seguidos, que abordem o trabalho (a exploração capitalista) como algo positivo e que mantenham o Estado como fonte primária do Direito, da justiça e das normas de conduta, uma vez que este, como foi dito, é o seu sofisticado meio de dominação. A ideologia desempenha um papel ativo nas relações sociais, diferentemente daquela concepção economicista atribuída ao marxismo, como esclarece Engels numa carta a J. Bloch, que segue:

De acordo com a concepção materialista da história, o elemento determinante final na história é a produção e reprodução da vida real. Mais do que isso, nem eu e nem Marx jamais afirmamos. Assim, se alguém distorce isto afirmando que o fator econômico é o único determinante, ele transforma esta proposição em algo abstrato, sem sentido e em uma frase vazia. As condições econômicas são a infraestrutura, a base, mas vários outros vetores da superestrutura (formas políticas da luta de classes e seus resultados, a saber, constituições estabelecidas pela classe vitoriosa após a batalha, etc., formas jurídicas e mesmo os reflexos destas lutas nas cabeças dos participantes, como teorias políticas, jurídicas ou filosóficas, concepções religiosas e seus posteriores desenvolvimentos em sistemas de dogmas) também exercitam sua influência no curso das lutas históricas e, em muitos casos, preponderam na determinação de sua forma (MARX e ENGELS, 2010, p.103-104).

É nesse aspecto que se pode perceber uma convergência conceitual entre a corrente marxista e o campo da Memória. Pois nesta abordagem de pensamento, o processo em que um grupo/coletividade busca passar a sua visão de mundo para outro, se denomina enquadramento de memórias (HALBWACHS, 1990). E esse mesmo processo para a o marxismo é quase sempre nada mais do que uma das formas de transmissão de ideologia da burguesia para o proletariado. As tradições inventadas são, portanto, exemplos de práticas aperfeiçoadas de enquadramento de memórias e ao mesmo tempo meios da classe dominante disseminar algumas das suas ideologias (HOBSBAWN \& RANGER, 2014). É enquadramento porque se trata da inculcação do Estado nacional de memórias que a maior parte da sua comunidade não presenciou. E é ideologia porque quem está por trás do Estado é a sua classe dirigente, a burguesia. 
A invenção da Tropicália se deu, dessa forma em um dos momentos de atualização da memória nacional. E para que isso seja mais bem compreendido é necessário que levante ao menos uma hipótese sobre qual a ideologia margeava aquele movimento. Mais do que uma "falsa consciência" ou "ilusão da realidade", a ideologia é uma "ilusão sistematizada da realidade", (VIANNA, 2021). Pois se não fosse assim, ela seria equivalente ao imaginário, Contudo os conceitos não se confundem, pois, enquanto no imaginário, tem-se uma ilusão da realidade feita por operação simples que é uma visão pouco aprofundada das coisas, na ideologia, há a figura do "ideólogo", um profissional que se torna especialista da produção pensamento para a burguesia, inclusive na produção cultural. "Os ideólogos e estes são os trabalhadores intelectuais (cientistas, filósofos, teólogos)" (VIANA, 2021).

Tem-se aí uma pista sobre as intenções dos principais tropicalistas de se forjarem como ideólogos. Marcos Napolitano (2007) revela, nesse sentido, o protagonismo de Caetano Veloso frente às discussões com outros artistas, críticos e intelectuais sobre os rumos da música e da cultura nacional, em meio às mudanças que ocorriam no Brasil.

Nisso repousa a hipótese neste texto sobre o projeto intelectual da Tropicália: os tropicalistas como elaboradores de uma ideologia distinta da ideologia do Estado nacional ora em vigor. Não necessariamente uma ideologia revolucionária, ou com o fito asfixiar o sistema capitalista. Porém munidos de um projeto de modernização dos costumes que a classe dominante brasileira, ou pelo menos os dirigentes do Estado, relutavam em fazer. Reforçando essa hipótese tem-se o depoimento do próprio Caetano Veloso (1997), contando que os tropicalistas viram na conjuntura histórica em que estavam - que incluía a consolidação da cultura de massa, a popularização da televisão e a expansão da indústria fonográfica, dentre outras coisas - a possibilidade de inserir na memória nacional, novas abordagens, outrora silenciadas.

\section{MEMÓRIA E IDENTIDADE NEGRA}

Sigamos com a canção Domingo no Parque. Há nela outra característica do programa da Tropicália: o legado modernista da ideia de "antropofagia" (NAPOLITANO \& VILLAÇA, 2016). Isso foi verificável no uso de instrumentos musicais estrangeiros, quando da apresentação no III Festival, e no recurso de efeitos musicais típicos da música pop, quando do seu lançamento no disco Tropicália ou Panis Et Circenses ${ }^{i i i}$ (NAPOLITANO, 2007), mas tudo 
sob a tônica de um ritmo (samba jongo), uma construção melódica e um tema comum às questões do Brasil.

Outra influência direta do movimento foi a Poesia Concreta (VOLCATO, 2015). Ela pode ser percebida ao longo do corpo da canção. Por exemplo, tem-se o jogo de linguagem com os nomes próprios “José” e "João” associados aos seus adjetivos "rei da brincadeira e rei da confusão", sendo que no final da narrativa, há uma inversão: as ausências dos fatos que adjetivaram os personagens, são respondidos pelos "ecos" (as vozes back vocals) dos seus

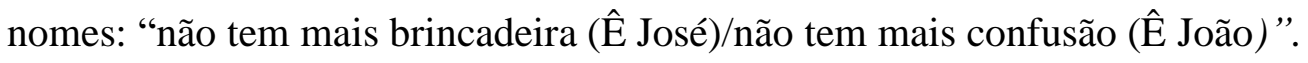

Ainda falando em jogo de palavras Domingo no Parque apresenta um tipo de linguagem, ao que parece inédito na canção brasileira: a metalinguagem e o diálogo com outros campos das artes - no caso, a narrativa do cinema. Carlos Rennó observou o caráter imagético das palavras: a cor vermelha do "sorvete de morango" e da "rosa" descritos na canção induz a uma mensagem subliminar de "sangue", simbologia do evento trágico que viria a acontecer no desfecho da narrativa. Acrescenta-se uma simbologia de "perigo". Nesse ponto da canção, as imagens de "José", "Juliana" e "João" se alternam como em uma cena crucial de um filme.

É ainda notável o contínuo uso de referências dos tropicalistas a músicas nacionais anteriores ao movimento. O personagem "João" da narrativa Domingo no Parque foi inspirado no personagem “João Valentão" de uma canção de Dorival Caymmi, consagrado cantor e compositor de uma geração anterior (LOPES, 2011). Com essa referência, confirma-se o projeto de se criar uma nova tradição musical brasileira, sem silenciar as contribuições das memórias do cancioneiro do passado (NERCOLINI, 2016).

Para além de tudo isso, também é possível demonstrar como essa canção reclama por uma identidade negra, embora não de forma tão direta quanto em outras. Constata-se que nela há elementos que evocam a memória da população preto-mestiça do Brasil: o andamento rítmico-melódico de capoeira, na qual os instrumentos têm a marcação de um berimbau e os back vocals respondem ao cantor principal. Ora, essa maneira de canto interativo é comum nas rodas de capoeira - dança e ao mesmo tempo arte marcial que se consagrou como um dos maiores bens simbólicos da população negra do Brasil, contra a os desmandos da escravidão e mais tarde contra a opressão do Estado burguês (LUZ, 2000). A respeito da dança que a capoeira produz, há de se lembrar de que é uma memória evocada pelo próprio corpo, como mostrou Muniz Sodré (1998) em relação ao samba, cuja matriz lhe é comum. 
Finalmente, tem-se na canção uma linha melódica repetitiva em forma de rondó em clara referência a uma "roda", como se a melodia fosse sendo conduzida na roda gigante do parque onde estão os protagonistas da narrativa. Aqui as expressões "roda gigante" e "girando" cumprem dupla função: a primeira é dar ideia de movimento da cena e criar elementos imagéticos para lhe dar dramaticidade. Quanto à segunda função, é mais ampla e simbólica, pois diz respeito ao uso da "roda" assim como da "gira", como elemento sagrado na memória das culturas negras antepassadas e no candomblé. É a simbologia da roda como algo que remete ao eterno processo do ciclo da vida, das passagens humanas para o plano material e espiritual. O começo, o fim e o recomeço continuamente (LUZ, 2000).

Um questionamento, a algo aparentemente óbvio, deve ser feito: por que e qual a pertinência de Gilberto Gil e dos tropicalistas colocarem em suas pautas as lutas por memórias e pela identidade negra? Grosso modo, a resposta seria: ao longo da História da nação houve um sistemático silenciamento de memórias das populações afrodescendentes no Brasil. É sempre necessário lembrar que várias abordagens nos campos das ciências sociais e humanas como, Lília Schwarcz (2002), Marco Aurélio Luz (2000), Kabengele Munanga (1999), João José Reis (1989), Florestan Fernandes (1972), dentre outros - têm revelado que desde o início da escravidão, na então colônia portuguesa, a população negra brasileira tem sofrido com os preconceitos, os impedimento de manifestações religiosas e culturais, as exclusões e as violências físicas e de outras naturezas da parte da sociedade como um todo e pelos meios repressivos do próprio Estado. E mais ainda: estudos revelam que as Ciências Sociais, a Medicina e o Direito trabalharam lado a lado, mesmo após a Abolição da Escravatura, com o intuito de manter a perseguição, a marginalização e até o extermínio desta população (PRUDENTE, 2016; SCHWARCS, 2002).

Segundo Sérgio Guimarães (2002) os resultados sociais dessa sistemática política opressora e de esquecimento resultaram numa dura condição: a pirâmide social brasileira tem direta correspondência na distinção étnica. A base da pirâmide - onde ficam os pobres - é quase em sua totalidade formada por pretos e mestiços, enquanto no topo - representando os ricos predomina de forma triunfal a população de brancos.

Dentre os resultados dessa distinção social pela etnia, têm-se também desfavoráveis condições dos negros em relação ao acesso à educação e qualificação para o trabalho (SALDAÑA, 2019) e, são más as condições de moradia, sanitárias e de condições de vida em geral. Tal situação infla a violência e como resultado tem-se que a taxa de pessoas negras 
assassinadas é mais que o dobro em relação ao de brancos ${ }^{\text {iv }}$, cada três presidiários no país dois são negros (DALAMPOLA, 2017).

Diante desses fatos, arguimos que um acervo de músicas populares que falem sobre as duras vivências dos negros pode se configurar como uma forma de arte engajada e em meio de lutas pelas memórias desta população.

A paridade entre a condição social e condição étnica, remete à análise da canção Nos Barracos da Cidade , cuja letra é de Gilberto Gil e a melodia é do compositor Liminha:

Nos barracos da cidade/Ninguém mais tem ilusão/No poder da autoridade/De tomar a decisão/E o poder da autoridade, se pode, não faz questão/Mas se faz questão, não/Consegue/Enfrentar o tubarão/Ôôô,ôô/Gente estúpida/Ôôô, ôô/ Gente hipócrita// E o governador promete,/Mas o sistema diz não/Os lucros são muito,/Grandes... ie, ie/E ninguém grandes quer abrir mão, não/Mesmo uma pequena parte/Já seria a solução/Mas a usura dessa gente/Já virou um aleijão/ (...) (p. 302).

Em sua letra, não há uma referência imediata à questão da negritude, mas o ritmo reggae dá-lhe a condição de suporte de memória do povo negro, visto que este gênero, nascido na Jamaica - país com população de etnia negra - foi ali largamente utilizado para fazer denúncias sociais e políticas. Na década de 1970 em diante, o contato de Gilberto Gil com autores como Bob Marley e Jimmy Cliff fê-lo ser um dos principais entusiastas na introdução do reggae no Brasil (GIL \& ZAPA, 2013)

Seguindo a tradição do reggae como forma de protesto, Gilberto Gil o incorporou à música popular brasileira no bojo da música engajada que se iniciara na década de 1960 . Gravada em 1985, Nos Barracos da Cidade já não era uma música de protesto (surgida na década de 1960), no sentido específico de ser uma luta contra a Ditadura Militar. A canção, na verdade, centrava-se na crítica às mazelas sociais e na denúncia dos governos inoperantes e demagogos do país. Criticava, dessa forma, a democracia burguesa que se anunciava e o legado social que a Ditadura estava deixando.

Diante da pobreza em que as massas, principalmente urbanas preto/mestiças, passaram a experimentar mais profundamente na década de 1980, a identidade reclamada nesta canção se dá pela identificação desta população na mesma condição de pobre, favelado e desiludido com o sistema político. Assim, o autor sem utilizar a palavra "negro", elabora um suporte de identidade negra, isto é, que a maior parte da população preta e mestiça do Brasil moravam em locais marginalizados, nos quais o Estado em sua função social é ausente. 
De certa maneira, essa canção tem o seu duplo com o Punk da Periferia. ${ }^{v i}$ Neste, a temática se assemelha e indica que Gilberto Gil quis usar em sua música a voz silenciada dos habitantes das zonas periféricas das cidades. Punk da Periferia tem como a denúncia dos marginalizados ao descaso do Estado, das autoridades e da sociedade burguesa como um todo, mas também o descontentamento contra as utopias. Trata-se de um quadro cru e chocante dos habitantes da periferia, que vivem na extrema pobreza:

Das feridas/Que a pobreza cria/Sou o pus/Sou o que de resto/Restaria aos urubus/Pus por isso mesmo/Este blusão carniça/Fiz no rosto/Este make-up pó caliça/Quis trazer assim/Nossa desgraça à luz.../Sou um punk da periferia/Sou da Freguesia do Ó/Ó! Ó ÓÓÓÓÓ Ó!/Aqui prá vocês! Sou da Freguesia...//Ter cabelo/Tipo índio moicano/Me apraz!/Saber que/Entraremos pelo cano/Satisfaz!/Vós tereis um padre/ Prá rezar a missa/Dez minutos antes/De virar fumaça/Nós/ocuparemos/A Praça da Paz...//Sou um punk da periferia/Sou da Freguesia do Ó/Ó! Ó Óóóóó Ó!/Aqui prá vocês!/Sou da Freguesia...//Transo lixo/Curto porcaria/Tenho dó/Da esperança vã/Da minha tia/Da vovó/Esgotados/Os poderes da ciência/Esgotada/Toda a nossa paciência/Eis que esta cidade/É um esgoto só...//Sou um punk da periferia/Sou da Freguesia do Ó Ó! Ó ÓÓÓÓó Ó!/Aqui pra vocês!/Sou da Freguesia... (RENNÓ, p. 267).

Se em Nos Barracos da Cidade há espaço para reordenação do espaço das cidades pelo proletariado, em Punk da Periferia, não há essa possibilidade. Vale ressalvar que a escolha do ritmo de punk, não é aleatória, pois esse estilo musical é um dos muitos gestados no contexto do movimento historicamente conhecido como contracultura que surgiu nos Estados Unidos e se consolidou na Grã-Bretanha, na década de 1970. De caráter fortemente questionador, suas letras demonstram a impossibilidades de ascensão e/ou conforto do proletariado urbano no sistema capitalista. Desnudam o capitalismo como uma demagogia (BIVAR, 1982). Nessa canção, o próprio título sugere uma situação mais adversa ainda do seu sujeito falante, já que a sua condição de proletário sem grandes possibilidades junta-se a condição de ser de um centro urbano de um país pobre, dito de Terceiro Mundo. A "Freguesia do Ó”, bairro de São Paulo, pode ser interpretada na canção como a periferia da periferia. Tem-se aqui também uma clara oposição entre a ideologia e memória oficial do Estado com a memória autenticamente aferida nos quadros sociais de memória dessa comunidade extremamente pobre e silenciada.

O "eu lírico" da canção diz que "das feridas que a pobreza cria". E mais chocante ainda: "sou o que de resto restaria aos urubus (...) Transo lixo, curto porcaria." (...). Percebe-se por isso que se em Nos Barracos da Cidade fala-se do proletariado ainda engajado, em Punk da 
Periferia fala-se do proletariado sem esperança, cuja força revolucionária é inexistente e nada lhe resta a não ser uma existência malograda, comparada ao lixo que o sistema capitalista industrial fabrica.

Na linguagem coloquial a expressão "Aqui pra vocês" é um imperativo chulo de um xingamento e ao mesmo tempo um desabafo. O sujeito falante quando a expressa, costuma utilizar um gesto socialmente considerado obsceno, do dedo médio para quem o ouve/vê, numa intenção de se dizer: "eu não aceito a sua imposição".

Mas é na canção A Mão da Limpeza ${ }^{v i i}$, composta em 1984, que a referência a negritude aparecerá explicitamente:

O branco inventou que o negro/Quando não suja na entrada/Vai sujar na saída/(...) Que mentira danada, ê//Na verdade a mão escrava/Passava a vida limpando/O que o branco sujava, /(...)/O que o negro pensava, ê//Mesmo depois de abolida a escravidão/Negra é a mão/De quem faz a limpeza/Lavando a roupa encardida, esfregando o chão/Negra é a mão/É a mão da pureza/Negra é a vida consumida ao pé do fogão/Negra é a mão/Nos preparando a mesa/Limpando as manchas do mundo com água e sabão/Negra é a mão/De imaculada nobreza//Na verdade a mão escrava/Passava a vida limpando/O que o branco sujava, ê/Imagina só/O que o branco sujava, ê/Imagina só/ Êta branco sujão ${ }^{10}$ (p. 288).

De forma direta, Gilberto Gil reflete sobre as condições de vida e de trabalho dos negros no Brasil, tomando como referência um ditado popular maledicente e racista contra o negro, de acordo com o testemunho do próprio autor (RENNÓ, 2000). Nessa canção, ele demonstra ao mesmo tempo, o traquejo na elaboração da letra da canção popular, o conhecimento histórico sobre escravidão e o seu resultado plasmado no cotidiano brasileiro que um(a) negro(a) faz o trabalho mais pesado e menos remunerado na sociedade brasileira.

O indivíduo negro não é apresentado como o culpado pela sua situação de inferioridade social. Pelo contrário, através do recurso de trocadilho, a expressão "mão da pureza" remete ao conceito de inocência ("mãos limpas"), ganhando um sentido conotativo, enquanto em outras referências a palavra "mão" está no denotativo e claramente indica a atividade laboral dos negros. O tema da ideologia racista é abordado no início da canção - "o branco inventou que o negro quando não suja na entrada/ Vai sujar na saída...” - quando ele demonstra que o conceito do "negro preguiçoso" apregoado no provérbio é uma invenção, ou seja, uma visão falsa da realidade, que caracteriza uma ideologia para legitimar uma opressão. O branco/colonizador dessa forma buscou operar um enquadramento de memória sobre o escravo para que ele se subjetivasse como "sujo" e "menor". O branco/burguês deu continuidade e reforçou esta visão. 
Novamente o autor se vale do recurso do jogo de linguagem. O intuito é demonstrar que houve uma inversão da verdade feita por um discurso histórico comprometido com a preservação de uma memória que era de interesse do Estado nacional, ou seja, uma História-memória.(NORA, 1993)

Conforme já foi dito, a música de Gilberto Gil sobre a negritude não se limita a ser suporte de memórias de lutas. Ela é também uma celebração da cultura dos povos negros (SANTOS, 2015) De forma que numa das mais famosas composições, a música Palco ${ }^{\text {viii, }}$ Gilberto Gil diz: "trago cesto de alegrias de quintais", fazendo uma referência direta aos cultos do candomblé que predominante se dão nos terreiros, localizados nos quintais das casas consagradas como templos. É a tradição africana como matriz. Dessa continuidade transatlântica $^{\text {ix }}$ tem-se a oralidade como viés de manutenção da memória dos povos, personalidades e reinos ancestrais africanos. O compositor Gilberto Gil talvez tenha sido o autor brasileiro que mais entendeu esse sentido duplo de continuidade na cantiga de origem africana. Há em sua obra uma contínua referência à tradição que, ao mesmo tempo em que se conserva, incorpora novas demandas acerca da identidade negra no Brasil. Tome-se: Babá Alapalá

Aganju, Xangô/ Alapalá, Alapalá, Alapalá/ Xangô, Aganju O filho perguntou para o pai:/ "Onde é que tá o meu avô/O meu avô, onde é que tá?"//O pai perguntou pro avô:/"Onde é que tá meu bisavô/Meu bisavô, onde é que tá?"//Avô perguntou ô bisavô:/"Onde é que tá tataravô/Tataravô, onde é que tá?"//Tataravô, bisavô, avô/Pai Xangô, Aganju//Viva egum, babá Alapalá!//Aganju, Xangô//Alapalá, Alapalá, Alapalá/Xangô, Aganju//Alapalá, egum, espírito elevado ao céu//Machado alado, asas do anjo Aganju/Alapalá, egum, espírito elevado ao céu/Machado astral,/ancestral do metal/Do ferro natural/Do corpo preservado/Embalsamado em bálsamo sagrado/Corpo eterno e nobre de um rei nagô/Xangô ${ }^{12}$ (RENNÒ, 2000 p.185).

Nela, mais uma vez os quadros sociais de memória (representados pela família, não somente nuclear, mas a ancestralidade.) são visivelmente evocados para celebrar o sagrado e, ao mesmo tempo, mencionar a tradição como parte da cultura negra.

Ressalva-se a semelhança da canção com trechos de duas cantigas da tradição jeje-nagô, transcritos e analisados por Marco Aurélio Luz (2000):

I.

II. Agongono (Angonglo, que teria vivido no século XVIII e início do século XIX) /Dadalho, que segundo Pierre Verger, seria Agassou, o vodum dos reis do Daomé. /Bepega, filho do rei Tegbessou /Sepazin, filha do rei Wegbadja./Dako, o rei Dakondonou 1625-1640)...../Desse, 
filho do rei Kapengla /Naite... mãe do rei Agonono (LUZ, 2000, pp. 9091). //

III. Pai Joaquim/pai Joaquim e a/pai Joaquim é o rei de Angola (...) (LUZ, 2000, p. 91)

Ambos os trechos de cantigas são mais que celebrações ou manifestações artísticas. Cada um se configura em "suporte imaterial" de memória que se converte em provas documentais sobre o passado. Na primeira, têm-se referência ao panteão dos ancestrais reais cultuados nas cantigas entoadas em um terreiro de candomblé ("a afamada Casa das Minas"), o que indicaria a origem dos terreiros ligada desde a sua fundação à vinda de parentes do Rei Ghezo ao Brasil. Enquanto, o segundo trecho é de um cântico mais presente em outra religião, a umbanda, que também muitas vezes utiliza o canto da tradição jeje-nagô, no intuito de rememorar as realezas ancestres. No trecho, o canto foi incorporado a gira e tem o mesmo efeito mnemônico.

Importa frisar que a ação de uma narrativa sobre um aspecto específico permite, a quem o decora, conhecer a cronologia do seu reino de origem e situar os fatos históricos de acordo com a referência feita no cântico (THOMPSON, 1992). No caso da tradição jeje-nagô, oralidade é essencial, pois, à época das construções dessas cantigas, tais povos não possuíam língua escrita. Gilberto Gil, assim, opera de forma dialógica para com a tradição ao imitá-la como suporte coletivo de memória, mas acrescenta à sua maneira individual de compor.

Em outros momentos, Gilberto Gil toma a ancestralidade como matriz para celebrar a festa da negritude na atualidade. É o caso da canção Filhos de Gandhi ${ }^{x}$, a qual foi composta e gravada no disco Refavela de 1977 no intuito de revitalizar um dos mais tradicionais blocos afro de carnaval de Salvador, Filhos de Gandhi, que no começo da década de 1970 estava caindo na indigência (RENNÒ, 2000). De acordo com Kywza Joana Fideles dos Santos (2014) tanto a composição desta canção, como a filiação de Gilberto Gil ao bloco afoxé Filhos de Gandhi, constituiu-se num ato de luta antirracista, pois nas décadas de 1970 e 1980, os blocos afro se tornaram símbolo da valorização da negritude brasileira e, principalmente, da evocação das memórias ancestrais da África.

É também o exemplo da canção Serafim ${ }^{x i}$, cuja celebração do panteão das divindades afro-brasileiras se mescla os infortúnios da condição humana (“apesar da travessia ruim"). Mas como o próprio nome sugere - travessia - a alegria da celebração há de prevalecer: 
Quando o agogô soar/O som do ferro sobre o ferro/Será como o berro do bezerro/Sangrado em agrado ao grande Ogum//Quando a mão tocar no tambor/Será pele sobre pele/Vida e morte para que se zele/Pelo orixá e pelo egum//Kabieci lê - vai cantando o ijexá pro pai Xangô//Emparrei, ora iêiê - pra Iansã e mãe Oxum//"Oba bi Olorum koozi": como deus, não há nenhum/Será sempre axé/Será paz, será guerra, serafim/Através das travessuras de Exu//Apesar da travessia ruim//Há de ser assim/Há de ser sempre pedra...

A direta referência aos orixás e divindades do candomblé faz jus ao que se tem dito até aqui sem, no entanto, ter definido o que são orixás. Pois bem, em uma definição sucinta, orixá é uma "categoria das divindades dos povos nagô-iorubá ligadas à vida e a natureza. Para a tradição, que comanda o universo, o movimento das coisas e a natureza. Ocupam patronatos, recebendo cultos específicos, coerentes com suas funções e mandos de poder" (LUZ, 2000). Para a tradição, cada pessoa tem um orixá que lhes acompanha, lhes dá sentido à vida e a seus atos (LUZ, 2000; COSTA 1974). Os espíritos, mesmo os considerados elevados e criadores das coisas, do mundo e do homem, como os "deuses" (para fazer uma comparação com a cultura europeia, Olorum, Oxalá e Exu) são orixás. A palavra ori significa "cabeça”, daí ser comum no candomblé a expressão santo de cabeça ${ }^{26}$. Dentro da tradição religiosa do candomblé, essas entidades têm o papel central de ligação do homem a sua espiritualidade, a sua memória arquetípica.

Aqui, assim como na canção, $K a \hat{o}^{x i i}$, tem-se outra contribuição de Gilberto Gil: a transposição de estilos que pertencem ao rol de canções religiosas, - e, portanto, que estavam circunscritos ao território sagrado - para o terreno da música popular, que é laica e muito difundida pelos meios de comunicação de massa. O que o autor pretendeu não foi fazer uma mera recordação ou cópia dos cânticos da cultura jeje-nagô, por razões ligadas às suas preferências religiosas. Ao fazer essa transposição, tomando uma matriz de música sagrada para a composição de uma música do gênero "canção", - que se caracteriza pela necessidade da identificação de um autor (TINHORÃO, 1986) - Gilberto Gil toma como base um meio de memória coletivo que é a cantiga jeje-nagô, transmitindo memórias de uma tradição, sob o invólucro de outro gênero musical: a canção popular. Este gênero goza de maior prestígio e aceitação social no Brasil e por isso é mais eficiente para o que pretende: reivindicar a identidade negra como uma das identidades da nação.

É sempre válido lembrar que Gilberto Gil rejeita em sua obra uma abordagem única e/ou apartada do negro na sociedade, e que as suas lutas pela memória não se confundem com uma visão passadista ou avessa às mudanças trazidas pela tecnologia. Na canção Pela 
Internet $^{x i i i}$, por exemplo, há um trecho que sintetiza o seu ponto essa abordagem. A web site que o eu lírico cria permite-o velejar pelas águas da informação levando, dentre outras coisas a tradição: "Que veleje nesse informar/Que aproveite a vazante da informaré/que leve um okiri do meu velho orixá/Ao porto de um disquete de um micro em Taipé"12 (RENNÒ, 2000).

Com o tempo, Gilberto Gil foi incorporando em suas obras sobre a negritude a ideia de que as lutas pela memória dos negros é uma questão internacional. Isso, de certa forma o alinha ao pensamento de Abdias Nascimento (2002), que cunhou o termo quilombolismo, no afã de conciliar a luta internacional dos negros - o Pan africanismo- com as propostas políticas do materialismo histórico. Esse fato marca maior aproximação do compositor com cantores como Miles Davis e Bob Marley. Dentre as inúmeras canções que demonstram essa compreensão internacionalista está a música Refavela ${ }^{x i v}$, feita na década de 1970 quando ele visitou casas populares feitas na Nigéria (RENNÓ, 2000).

O internacionalismo negro de Gilberto Gil não se encerra na crítica e nos lamentos. Antes ele promoveu um verdadeiro intercâmbio cultural e de agendas entre os povos pretos e mestiços do mundo. Por exemplo, a gravação da canção Lamento Africano, recolhida do folclore angolano (RENNÒ, 2000) e as próprias versões em português de canções de Bob Dylan

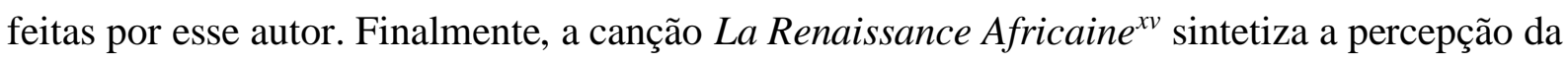
luta dos negros como uma agenda internacionalista e celebra o "renascimento da África", como um retorno a uma memória de reinos e nações que o colonialismo e o capitalismo não conseguiram silenciar:

L'homme plein de dignité/ Sa nature, ses dieux,/Son histoire et l'au delà/ L'homme et son paysage aimé/Tout est là devant ses yeux/Tout dedans le baouba// La renaissance africaine/La renaissance africaine/Et sa puissance/La renaissance africaine/La renaissance africaine/Avec sa dance// C'est l'afrique libertée/ C'est l'afrique et ses idées/ De sagesse et de vigueur// C'est l'afrique et sa mission/ Clé pour la vrai construction/ Du monde civilizé// Son peuple, son territoire/ Qui s'étendent en diaspora/ Jusqu'à la fin de la terre// En europe, en amerique/ C'est toujour l'esprit d'afrique /La nouveauté qui prospere// Ses enfants, ses gens musclés/ Ses femmes d'outre beauté/ Une beauté noir-nuit/ Continent le plus agé/ Les vieux temps nous ont laissé/ Sa mythologie, sa vie. (GIL, 2016).

À civilização reivindicada pelo homem branco colonizador e empreendedor do mundo, Gilberto Gil propõe uma civilização que dialoga com a sabedoria da tradição e do mito. $\mathrm{O}$ baobá, na tradição do candomblé é a representação do espírito da pessoa e do africano (AYRÁ, 2010). É uma árvore conhecida pela sua longevidade, tamanho e beleza. Por isso, em muitas 
tribos africanas as decisões eram tomadas coletivamente ao seu redor. Diz-se também que se um morto for sepultado dentro de um baobá, a sua alma viverá enquanto a árvore existir - o que leva pelo menos mil anos. Além do mais a árvore é para a Tradição, o símbolo da fertilidade, que remete ao renascimento. Por tudo isso, ela foi aos poucos sendo considerado símbolo de resistência dos africanos oprimidos (LUZ, 2000). Nessa canção, o baobá se impõe como alegoria nessa perspectiva e na perspectiva da alegoria renascimento que as árvores costumam serem colocadas.

A diáspora africana, situação trazida pelas viagens transatlânticas da escravidão, tornase um vetor de memória para a verdadeira liberdade humana, a saber, que os negros e a negritude circulam pelos confins da Terra e que no pan-africanismo está a "chave para a verdadeira reconstrução do mundo civilizado". O conceito de civilização em Gilberto Gil não se confunde com o eurocêntrico - que se opera por silenciamentos de memórias de outros povos. Pelo contrário, ele reclama pelas vozes de memórias e identidades até então silenciadas para que façam parte de uma sociedade pluralizada e mais igualitária.

\section{CONCLUSÃO}

O cantor e compositor Gilberto Gil logrou êxito no uso da música popular como suporte de memórias, no afã de se estabelecer como militante das causas da negritude. Sua militância suas lutas pelas memórias - se iniciou com o surgimento do movimento musical Tropicália. A canção Domingo no Parque, já continha as principais características daquele movimento, cujos contornos eram da busca por uma música cuja linguagem é acessível à população de todas as classes sociais e, ao mesmo tempo conservar o compromisso estético tanto na letra, quanto na melodia e, sobretudo, a criticidade das desigualdades sociais e da Ditadura Militar que, ora se instalara no país.

Uma questão que deve ser enfatizada é o fato do profundo sucesso que o movimento Tropicália teve no mercado brasileiro, projetando os seus principais artistas no cenário nacional, com boas vendagens de discos e shows, e, no caso da dupla Caetano Veloso e Gilberto Gil, até um programa de TV, chamado Lindo e Maravilhoso (VELOSO, 1997; NERCOLINI 2016). Esse sucesso se manteve por algumas décadas após o encerramento do movimento (no final de 1969, por conta do exílio de ambos os artistas), tendo a obra de Gilberto Gil, portanto, sido disseminada em todas as camadas sociais do Brasil, o que quer dizer (e isso nos importa) que a sua luta pelas memórias da negritude não foi algo restrito apenas a um único lugar social. 
A princípio, a militância de Gilberto Gil nas lutas pelas memórias dos negros era marcada por uma pauta mais nacionalista (LOPES, 2011). Nas primeiras canções, a questão da negritude estava ligada às mazelas de uma sociedade que se formou a partir da escravidão. Porém, percebe-se que durante o seu exílio do compositor, começou uma nova etapa da luta pelas memórias da negritude. Sendo assim, há da sua parte, divulgação de ritmos internacionais de origens negras por Gilberto Gil - principalmente o reggae - e a incorporação desses ritmos e até de novos gêneros à música brasileira.

Os eixos temáticos da obra do compositor, classificados por Kywza Joana Pereira Fideles dos Santos (2015), demonstram que há uma clara intenção da sua parte em inserir um conjunto de memórias da negritude ao longo da História, como parte da memória nacional, mas sem incorrer no perigo de um discurso estereotipado ou com ênfase em apenas um tipo de memória. Assim, concomitantemente ao lamento contra o racismo e à crítica da situação social da negritude. (Exemplo de A mão da Limpeza, Funk da Periferia, Sarará Miolo e Extra). Há a celebração das memórias dos reinos negros ancestrais, bem como das festas populares e das contribuições da população preto-mestiça para a História da nação brasileira e da questão da negritude como uma pauta internacional. (Exemplo de Filhos de Gandhi, Lamento para Mãe Menininha; Zumbi: a Felicidade Guerreira, Logunedé e La lune de Goré e Le Renasçaisse Africaine.).

A Tropicália não pretendeu ser um rompimento com a memória nacional. Seu projeto foi colocar-se como parte dela, embora de maneira crítica, atualizando a pauta da música brasileira com questões diversas, dentre elas a questão social e a questão da negritude no Brasil. Nesse sentido, pode-se arguir que a Tropicália é um movimento conservador. Todavia, essas novas pautas abordadas pelos tropicalistas, e especialmente a pauta da negritude, entraram definitivamente no rol das questões abordadas na música brasileira, se tornando assim, suportes de memórias das e identidades negras do Brasil.

\section{NOTAS}

\footnotetext{
${ }^{\text {i }}$ Este artigo se baseia na Dissertação de Mestrado com título homônimo, que o autor defendeu em 2017 no Programa de Pós Graduação em Memória e Educação, da Universidade Estadual do Sudoeste da Bahia, sob a orientação da Prof ${ }^{a}$. Dr ${ }^{a}$ Maria Aparecida Silva de Sousa.

ii A outra canção que também pode ser considerada um marco inicial da Tropicália é "Alegria Alegria”, de Caetano Veloso, que também concorreu no mesmo festival.

iii Gravadora Philips Records, 1968. Este disco é considerado o manifesto do movimento tropicalista.

iv Dados do IBGE, reeditados pela Revista Exame, disponíveis em: https://exame.com/brasil/ibge-populacaonegra-e-principal-vitima-de-homicidio-no-brasil/ Acesso: 12.de setembro de 2020.

v Décima Quarta Faixa do disco Dia Dorim Noite Neon. Ano de Gravação: 1985. Gravadora: Werner Music.
} 


\footnotetext{
${ }^{v i}$ Sexta Faixa do disco Extra. Ano: 1983. Gravadora: Werner Music

vii Sexta faixa do disco Raça Humana. Ano de Gravação: 1984. Gravadora: Warner Music.

viii Segunda faixa do disco Luar. Ano: 1981. Gravadora: Warner, Music Brasil.

ix Conceito de Kywza Joana Fideles dos Santos (2015) para designar a perpetuação das memórias dos povos africanos após sereme escravizados e dispersarem para outros continentes na diáspora negra (SANTOS, 2014).

${ }^{x}$ Segunda faixa do Lado D do disco Gil \& Jorge Ogum Xangô. Ano:1975. Gravadora Philips Records.

xi Quinta faixa do disco Parabolicamará. Ano 1991. Gege Produções Artísticas.

xii Sexta faixa do disco O Sol de Oslo. Ano: 1998. Gravadora: Biscoito Fino

xiii Décima faixa do disco Quant. Ano de gravação: 1995. Gravadora: Mesa/Bluemoom Recordings

xiv Primeira Faixa do disco Refavela. Ano:1977. Gravadora Warner Music.

${ }^{\mathrm{xv}}$ Sexta faixa do disco Banda Larga Cordel. Ano de gravação: 2008. Gravadora Warner Music.
}

\section{REFERÊNCIAS}

AYRÁ, João Batista. Baobá, a Árvore Sagrada da África. 21 de maio de 2010. Artigo disponível em <http://brasilcandombleverdade.blogspot.com.br/2010/05/baobaa-arvoreafricana-sagrada.html> Acesso: 12 de agosto de 2016.

BIVAR, Antonio. O que é Punk. São Paulo: Brasiliense, 1982.

CARVAlHO, Pedro Henrique Varoni de. A Voz que Canta na Voz que Fala. Poética e Política na Trajetória de Gilberto Gil. Disponível em:

<https://repositorio.ufscar.br/handle/ufscar/5630? show=full> Acesso: 15 de junho de 2016. . O que é Ideologia. Editora Brasiliense. Brasília. 1980.

DALAMPOLA, Kaique. Negros representam dois terços da população carcerária brasileira. Informativo. Disponível em: <https://noticias.r7.com/brasil/negros-representamdois-tercos-da-populacao-carceraria-brasileira-08122017>. Acesso em: 08/12/2017.

FONTELES, Bené. Giluminoso: A Poética do Ser. Brasília: Editora Universidade de Brasília; São Paulo, SESC. 1999.

FERNANDES, Florestan. O Negro no Mundo dos Brancos. São Paulo: Difel, 1972 GUIMARÃES, Antônio Sérgio Alfredo. Classes, Raças e Democracia. São Paulo: Editora 34, 2002.

GIL, Gilberto \& ZAPPA, Regina. Gilberto Bem Perto. Rio de Janeiro: Nova Fronteira, 2013.

HALBWACHS, Maurice. A Memória Coletiva. São Paulo: Revista dos Tribunais, 1990.

HOBSBAWM, Eric \& RANGER, Terence (orgs.) A Invenção das tradições. $9^{a}$ edição. Rio de Janeiro: Paz e Terra, 2014.

MEDEIROS, Ruy Hermann Araújo. Memória Compartilhada e História: Entre Alienação e Ideologia. Disponível em: <http://ruymedeiros.blogspot.com/2015/04/universidadeestadual-do-sudoeste-da.html>. Acesso: 25 de março de 2016. 
NAMER, Gerard. Posfácio In: Los Marcos Sociales de La Memoria. Disponível em: $<$ https://www.scribd.com/doc/102662867/Los-marcos-sociales-de-la-memoria-MauriceHalbwachs>. Acesso: 24 de julho de 2016.

NAPOLITANO, Marcos. História \& Música. História Cultural da Música Popular. Belo Horizonte. Autêntica, 2002.NASCIMENTO, Abdias. O Quilombolismo. $2^{\text {a }}$ Edição. Brasilía/Rio de Janeiro: Fundação Cultural Palmares/OR Editora. 2002.

NORA, Pierre. Entre Memória e História. A Problemática dos Lugares. Revista Do Programa de Pós-Graduação em História, PUC, SP. Disponível em:

<https://revistas.pucsp.br/revph/article/view/12101/8763> Acesso: 13 de setembro de 2020.

KONDER, Leandro. A Questão da Ideologia. São Paulo: Editora Schwartz Ltda, 2003.

LOPES, Cássia. Gilberto Gil - A Poética e Política do Corpo, São Paulo: Perspectiva, 2012.

LUZ, Marco Aurélio de Oliveira. Agadá. Dinâmica da Civilização Africano-Brasileira. Salvador: EDUFBA, 2000.

MARX e ENGELS, Karl e Friedrich. Cultura, arte e literatura: textos escolhidos; trad. José Paulo Netto e Miguel Makoto Cavalcanti Yoshida. $1^{a}$ ed.: São Paulo. Expressão Popular, 2010.

MENESES, Ulpiano T. Bezerra de. A História, cativa da memória? Para um mapeamento da memória no campo das ciências sociais, Revista do Instituto de Estudos Brasileiros/USP, São Paulo, v.34, p. 9-23, 1992.

MUNANGA, K. Rediscutindo a Mestiçagem no Brasil: Identidade Nacional Versus Identidade Negra. Petrópolis, RJ: Vozes, 1999.

NAPOLITANO, Marcos. A Síncope das Ideias. São Paulo: Editora Fundação Perseu Abramo, 2007.

NAPOLITANO, Marcos \& VILLAÇA, Mariana Martins. Tropicalismo: As Relíquias do Brasil em Debate. Revista Brasileira de História. Disponível em <http://www.scielo.br/scielo.php?script=sci_arttext\&pid=S0102-01881998000100003> Acesso 12 de julho de 2016.

NERCOLINI. Marildo José. A Música Brasileira Repensa a Identidade e Nação. Revista FAMECOS. Porto Alegre, n.31. dez. 2016. Disponível em:

$<$ https://revistaseletronicas.pucrs.br/ojs/index.php/revistafamecos/article/view/3402>. Acesso: 13 de abril de 2016.

PARANAGUÁ, Paulo Antônio. A Invenção do Cinema Brasileiro: Modernismo em Três Tempos. 1 ${ }^{a}$. Edição. Rio de Janeiro: Casa da Palavra, 2014.

PEREIRA, Letícia Maria de Souza. Gilberto Gil e o Corpo: Uma Questão Política. Trabalho apresentado no II ENECULT - Encontro de Estudos Multidisciplinares em Cultura, realizado de 03 a 05 de maio de 2006, na Faculdade de Comunicação/UFBa, Salvador-Bahia- 
Brasil. Disponível em: < http://www.cult.ufba.br/enecul2006/leticia_pereira.pdf.> Acesso: 05 de setembro de 2015.

POLLAK, Michael. Memória, Esquecimento, Silêncio. Rio de Janeiro: Estudos Históricos, vol. 2, n.3, 1989.

PRUDENTE, Maria Eunice de Jesus. O Negro na Ordem Jurídica Brasileira. 1989. Disponível no site da Revista da Faculdade de Direito da Universidade de São Paulo. endereço:< http://www.revistas.usp.br/rfdusp/article/view/67119>. Acesso: 12 de agosto de 2016.

PRADINI, Paola Diniz. A Cor na Voz. São Paulo 2013. Disponível em <:http://www.teses.usp.br/teses/disponiveis/27/27152/tde-30012014-105233/pt-br.php.> Acesso: 07 de outubro de 2015.

REIS, João José \& SILVA, Eduardo. Negociação e Conflito. - A Resistência Negra no brasil Escravista. São Paulo: Cia das Letras, 1989.

RENNÓ, Carlos. Org. Gilberto Gil - Todas as Letras. São Paulo: Cia das Letras, 2000.

SALDAÑA, Paulo. 4 em cada 10 Jovens Negros não terminaram o Ensino Médio. Jornal Folha de São Paulo. 01/09/2019. Disponível em:

$<$ https://www1.folha.uol.com.br/educacao/2019/09/4-em-cada-10-jovens-negros-naoterminaram-o-ensino-medio.shtml>. Acesso: 12.de setembro de 2020.

SANTOS, Kywza Joana Fideles dos. Dos Orixás ao Black is Beautiful: A Estética da Negritude na Música Popular Brasileira. Tese de Doutorado em Comunicação Da Universidade Federal de Pernambuco. 2014. Disponível em <https://repositorio.ufpe.br/bitstream/123456789/13892/1/TESE\%20VERS\%c3\%83O\%20FI NAL\%20-\%20IMPRESSA\%20PARA\%20BIBLIOTECA.pdf> Acesso: 17 de julho de 2019

SCHWARCZ, Lília. O Espetáculo das Raças. São Paulo: Cia das Letras, 2002. SODRÉ, Muniz. Samba, o Dono do Corpo. Rio de Janeiro: Mauad, 1998.

SILVA, Uelber Barbosa. Racismo e Alienação. São Paulo: Instituto Lukács. 2012.

TINHORÃO, José Ramos. Pequena História da Música Popular Brasileira. São Paulo: Editora Círculo do Livro, 1986.

THOMPSON, Paul. A Voz Do Passado: Histórias de Vidas como Patrimônio da Humanidade. São Paulo: Paz e Terra, 1992.

VELloso, Mônica Pimenta. Os Intelectuais e a Política no Estado Novo. Fundação Getúlio Vargas. Centro de Pesquisa e Documentação de História Contemporânea no Brasil. Rio de Janeiro. 1987. Disponível em: <http://bibliotecadigital.fgv.br/dspace/bitstream/handle/10438/6604/803.pdf?sequence=1> Acesso: 13 de maio de 2016.

VELLOSO, Mabel. Gilberto Gil. São Paulo: Moderna, 2002. 
VELOSO, Caetano. Verdade Tropical. São Paulo: Cia das Letras, 1997.

VIANA, Nildo. Imaginário e Ideologia: As Ilusões nas Representações Cotidianas e no Pensamento Complexo Revista Eletrônica Informe e Crítica. Disponível em $<$ https://informecritica.blogspot.com/2015/01/imaginario-e-ideologia-as-ilusoesnas.html?m=0>. Acesso: 02 de junho de 2021.

VIANNA, Hermano. O Mistério do Samba. Rio de Janeiro: Zahar, 1995.

VOLCATO, Luciana. Da Bossa Nova a Tropicália. Disponível em:

<http://www.lume.ufrgs.br/handle/10183/49626>. Acesso: 07 de dezembro de 2015. 